\title{
Genotyping of selection-significant polymorphisms of cattle of the Western Siberia
}

\author{
Nikolai Kochnev 1,*, Galina Goncharenko ${ }^{2}$, Sergei Mager ${ }^{2}$, Anastasiya Unzhakova ${ }^{1}$, and \\ Kirill Shatokhin ${ }^{1}$ \\ ${ }^{1}$ Novosibirsk State Agrarian University, Novosibirsk, Russia \\ ${ }^{2}$ Siberian Federal Research Centre for AgroBiotechnology, RAS, Krasnoobsk, Novosibirsk region, \\ Russia
}

\begin{abstract}
The article presents the results of genotyping of 156 Simmental cows for the genes of kappa casein $(C S N 3)$, beta-lactoglobulin $(B L G)$, alpha-lactalbumin $(L A L B A)$ and leptin $(L E P)$. Studies have shown that the population for all genes is in a state of equilibrium distribution of genotypes, which indicates the absence of factors that change allele frequencies. For the $C S N 3$ gene, the frequency of genotypes $A / A, A / B$, and $B / B$ is $0.583,0.385$, and 0.032 ; alleles $A$ and $B-0.776$ and 0.224 . For the $B L G$ gene, the frequency of the corresponding genotypes is $0.449,0.455$, and 0.096; alleles $A$ and $B-0.676$ and 0.324 . The occurrence of the $L A L B A$ gene genotypes is as follows: $A / A-0.513, A / B-0.429, B / B-0.058$; allele $A-0.728$, allele $B-0.272$. Distribution of genotypic classes of the $L E P$ gene: $C / C-0.429, C / T-0.481, T / T-0.09$; frequency of alleles $C$ and $T-$ 0.67 and 0.33 . The observed population structure with a low frequency of $\mathrm{B} / \mathrm{B}$ genotypes for the $C S N 3$ and $B L G$ genes associated with proteinmilkability, but a relatively high level of heterozygosity, demonstrates a stable equilibrium of allele frequencies, which is possible in the case of selection in favor of heterozygotes.
\end{abstract}

\section{Introduction}

The diversity of organisms is the basis of microevolution processes in populations. Preserving the genetic diversity of breeds is one of the most discussed issues in modern animal husbandry [1]. Many papers have been devoted to the study of general intraspecific variability and DNA polymorphism in connection with different genetic productivity potential and adaptive capabilities of breeds. It is believed that a large number of polymorphic loci and heterozygosity increase the adaptive properties of the population $[2,3]$. Some studies have shown systematic selection of heterozygotes in the reproductive group as the most effective part of the population [4]. The mechanism of connection between heterozygosity and adaptive potential of animals is considered from the point of view of polymorphism of neutral loci [5], or interaction of expression products of strictly defined genes [2]. In natural populations, there are evolutionarily developed ways to preserve genetic diversity, such as migration of males from one subpopulation to another

* Corresponding author: kochnev@nsau.edu.ru 
$[6,7]$.

In dairy farming, the risk of reducing genetic diversity is significantly higher due to the use of seed from a small number of producers, linear breeding and absorption crossing. Large-scale holsteinization of dairy cattle has led to the disappearance of many native species. The genetically effective population size is reduced due to reduced viability and fertility, and the allele pool is depleted due to the loss of some alleles through random processes [6, 8]. In addition, unilateral selection by milk yield for the first 305 days of lactation $[9,10,11]$ is practiced in animal breeding, which contributes to the fixation of the so-called polygenic complex of high milk productivity, which also reduces genetic diversity. Thus, the development of methods for controlling and preserving the genetic diversity of herds is an urgent problem.

Molecular genetic methods for controlling genetic diversity are currently the subject of scientific discussion [12, 13, 14]. The most informative method for monitoring heterozygosity has not yet been determined. A method for typing the polymorphism of microsatellite loci was proposed $[15,16,17,18]$. However, as the authors note, this approach may not be informative enough due to the high mutability of satellite DNA, and in this case the probability of heterozygosity of each of the studied loci is quite high [2]. In addition, a number of studies have not found conclusive evidence of microsatellites involvement in the maintenance of adaptive function in animals [19]. Consequently, analysis of the genetic diversity of satellite DNA is of interest only as a tool for phylogenetic analysis. Another equally popular method is high- and medium-density SNP chipping [20]. The disadvantage of this method is the high cost of research. However, SNP chipping allows to study the polymorphism of various morphofunctional DNA fragments evenly distributed across the genome. Some of the methods involve only monitoring of the most mutable structural genes [21].

Studying single-nucleotide polymorphisms of structural genes by dispersing restriction fragments in a semiconductor electrophoretic gel can be an effective way to monitor genetic diversity [22]. In cattle, SNP are widely studied in the genes of milk proteins - kappacasein, lactoalbumin, in the genes of the hormonal system - lactogenic hormone, progesterone, somatotropic hormone, and others. Research is mainly focused on the search for genetic markers of productivity. The object of our research was to study the genetic diversity of cattle breeds bred in the Western Siberia by the genes of kappa-casein (CSN3), beta-lactoglobulin $(B L G)$, alpha-lactalbumin $(L A L B A)$ and leptin $(L E P)$. The $C S N 3, B L G$, and $L A L B A$ genes control the synthesis of the corresponding milk proteins [23]. $L E P$ is a member of the family of fat metabolism genes [24]. The article presents the results of evaluating the polymorphism of these loci in the Simmental breed population.

\section{Materials and methods}

The blood of 156 Simmental cattle cows was used for molecular genetic studies. The average milk production per lactation is more than $8000 \mathrm{~kg}$ of milk, which indicates a high genetic potential of animals. Studies were conducted in the laboratory of biotechnology of the Siberian Scientific-Research and Design-Technological Institute of Animal Husbandry of the Siberian Federal Scientific Center of Agrobiotechnology of the RAS. DNA was isolated from the blood of canned EDTA KZ using a kit for extraction from the clinical material "Ampli Prime DNA-Sorb-B" according to the prescription of the manufacturer "NextBio" LLC. Detection of gene polymorphism was performed according to the description [25] using the C1000 "BioRad" amplifier. The results were identified using the gel documenting system E-Box-CX5.TS-20.

Statistical processing of the obtained data was carried out using computer programs RStudio and Microsoft Exel, as well as using generally accepted methods [26]. The 
significance of differences in the frequencies of genotypes and alleles was assessed using the Student's t-test [27]. For multiple comparison of samples, the Student's t-test was calculated with the Bonferroni correction [28]. Verification of the correspondence of the actual frequency distribution of genotypes to the theoretically expected frequency distribution was performed using the $\chi^{2}$ (chi-square) criterion [29].

\section{Research results}

Molecular genetic studies of animals based on genes associated with indicators of milk productivity were aimed at finding the uniqueness and originality of the Simmental breed bred in the Western Siberia. The genotypic structure of the population sample was evaluated in comparison with other breeds, as well as to determine the prospects for using these genes as markers of genetic diversity in dairy cattle.

Each breed has its own phenotypic and genetic characteristics. The population-genetic structure is formed under conditions of a random combination of alleles and is maintained for generations in a state of gene balance. Changes can occur under the influence of a number of factors, the most significant of which are the following: frequency of alleles and genotypes in progenitors; introduction from other populations; selection pressure; gene drift $[6,22,30,31]$. In our study, the actual ratio of genotypes in the Simmental breed for all genes corresponded to the theoretically expected one according to the Hardy-Weinberg formula (tables 1-4), which indicates that there is no significant influence of these factors at the moment. Analysis of the genetic structure of Simmental cattle in comparison with other breeds revealed a similar genotypic distribution for the CSN3 gene. The similarity is shown in the low frequency of occurrence of homozygotes $\mathrm{B} / \mathrm{B}$, not exceeding $8 \%$ (table 1 ). It can be assumed that a similar genotypic structure could have been formed in breeds during long-term selection only by the milk yield of cows. Khayertdinov et al. [23] note that animals homozygous for the allele $\mathrm{B}$ of the CSN3 gene have a higher protein content in comparison with their peers, and the protein content negatively correlates with milk yield [11]. Hence, selection by milk yield could lead to a decrease in the protein content in milk due to the elimination of the $\mathrm{B}$ allele. In addition, if bulls with genotypes $A / A$ and $A / B$ as higher-yielding participate mainly in the reproduction of the herd, then their descendants will have a low proportion of B/B homozygotes. This could be the conclusion, if you do not pay attention to the low frequency of occurrence of $\mathrm{B} / \mathrm{B}$ homozygotes also in meat breeds: limuzinskaya and hereford [32]. Probably, the low frequency of this allele should be associated with the mutation process, as a result of which a new variant of the gene appeared from the ancestral form of the $A$ allele.

Table 1. Genetic structure of cattle breeds by the $C S N 3$ gene

\begin{tabular}{|c|c|c|c|c|c|c|c|c|}
\hline \multirow{2}{*}{ Breed } & \multirow{2}{*}{$\mathrm{n}$} & \multicolumn{3}{|c|}{ Genotype frequency } & \multicolumn{2}{c|}{ Allele frequency } & \multirow{2}{*}{ Source } \\
\cline { 3 - 8 } & $\mathrm{n}$ & $A / A$ & $A / B$ & $B / B$ & $A$ & $C$ & $\chi^{2}$ & \\
\hline $\begin{array}{c}\text { Simmental } \\
\text { (Western Siberia) }\end{array}$ & 156 & $\begin{array}{c}0.583 \pm \\
0.039\end{array}$ & $\begin{array}{c}0.385 \pm \\
0.039\end{array}$ & $\begin{array}{c}0.032 \pm \\
0.014\end{array}$ & $\begin{array}{c}0.776 \pm \\
0.024\end{array}$ & $\begin{array}{c}0.224 \pm \\
0.024\end{array}$ & 0.011 & OS \\
\hline $\begin{array}{c}\text { Russian Black Pied } \\
\text { (Belarus) }\end{array}$ & 289 & $\begin{array}{c}0.651 \pm \\
0.028\end{array}$ & $\begin{array}{c}0.311 \pm \\
0.027\end{array}$ & $\begin{array}{c}0.038 \pm \\
0.011\end{array}$ & $\begin{array}{c}0.806 \pm \\
0.023\end{array}$ & $\begin{array}{c}0.194 \pm \\
0.023\end{array}$ & 0.003 & {$[33]$} \\
\hline $\begin{array}{c}\text { Russian Black Pied } \\
\text { (Tatarstan) }\end{array}$ & 345 & $\begin{array}{c}0.590 \pm \\
0.026\end{array}$ & $\begin{array}{c}0.368 \pm \\
0.026\end{array}$ & $\begin{array}{c}0.046 \pm \\
0.011\end{array}$ & $\begin{array}{c}0.770 \pm \\
0.023\end{array}$ & $\begin{array}{c}0.230 \pm \\
0.023\end{array}$ & 1.287 & {$[34]$} \\
\hline Holstein (Tatarstan) & 1071 & $\begin{array}{c}0.445 \pm \\
0.015^{* * *}\end{array}$ & $\begin{array}{c}0.471 \pm \\
0.015^{*}\end{array}$ & $\begin{array}{c}0.084 \pm \\
0.008^{* *}\end{array}$ & $\begin{array}{c}0.680 \pm \\
0.014\end{array}$ & $\begin{array}{c}0.320 \pm \\
0.014\end{array}$ & 4.370 & {$[35]$} \\
\hline
\end{tabular}




\begin{tabular}{|c|c|c|c|c|c|c|c|c|}
\hline $\begin{array}{c}\text { Kholmogorskaya } \\
\text { (Tatarstan) }\end{array}$ & 164 & $\begin{array}{c}0.665 \pm \\
0.037\end{array}$ & $\begin{array}{c}0.317 \pm \\
0.036\end{array}$ & $\begin{array}{c}0.018 \pm \\
0.010\end{array}$ & $\begin{array}{c}0.823 \pm \\
0.030\end{array}$ & $\begin{array}{c}0.177 \pm \\
0.030\end{array}$ & 1.301 & [36] \\
\hline
\end{tabular}

As in the case of the $C S N 3$ gene, the most preferred by $B L G$ gene is the $B / B$ genotype, which is associated with an increase in their controlling proteins and better coagulation properties. The frequency of this genotype in Simmentals was also low and did not exceed $10 \%$. In comparison with black-and-white and Kholmogorsky cattle, it is 2 and 4 times smaller, respectively (table 3). A similar pattern was established for the LALBA (table. 4) and $L E P$ (table 5) genes. Few $B \backslash B$ and $T / T$ homozygotes were found in the structure of Simmentals, and the ratio of other genotypes is approximately the same. In comparison with the Kholmogorskaya breed, the $B / B$ frequency for the $L A L B A$ gene in Simmentals is lower $(\mathrm{P}<0,001)$, and the proportion of $A / A$ is higher $(\mathrm{P}<0,01)$ with equal occurrence of heterozygotes. The $L E P$ gene shows a similar pattern. In black-and-white cattle, heterozygotes for the $B L G$ and $L A L B A$ genes predominate, in contrast to Simmentals.

Table 2. Genetic structure of cattle breeds by the $B L G$ gene

\begin{tabular}{|c|c|c|c|c|c|c|c|c|}
\hline \multirow{2}{*}{ Breed } & \multirow{2}{*}{$\mathrm{n}$} & \multicolumn{3}{|c|}{ Genotype frequency } & \multicolumn{2}{|c|}{ Allele frequency } & \multirow{2}{*}{$\chi^{2}$} & \multirow{2}{*}{ Source } \\
\cline { 3 - 8 } & & $A / A$ & $A / B$ & $B / B$ & $A$ & $C$ & $\chi^{2}$ & \\
\hline $\begin{array}{c}\text { Simmental } \\
\text { (Western Siberia) }\end{array}$ & 156 & $\begin{array}{c}0.449 \pm \\
0.040\end{array}$ & $\begin{array}{c}0.455 \pm \\
0.040\end{array}$ & $\begin{array}{c}0.096 \pm \\
0.024\end{array}$ & $\begin{array}{c}0.676 \pm \\
0.026\end{array}$ & $\begin{array}{c}0.324 \pm \\
0.026\end{array}$ & 0.002 & OS \\
\hline $\begin{array}{c}\text { Russian Black Pied } \\
\text { (Belarus) }\end{array}$ & 289 & $\begin{array}{c}0.246 \pm \\
0.025^{* * *}\end{array}$ & $\begin{array}{c}0.481 \pm \\
0.029\end{array}$ & $\begin{array}{c}0.273 \pm \\
0.025^{* * *}\end{array}$ & $\begin{array}{c}0.486 \pm \\
0.029^{* * *}\end{array}$ & $\begin{array}{c}0.514 \pm \\
0.029^{* * *}\end{array}$ & 0.400 & {$[33]$} \\
\hline $\begin{array}{c}\text { Kholmogorskaya } \\
\text { (Tatarstan) }\end{array}$ & 164 & $\begin{array}{c}0.122 \pm \\
0.026^{* * *}\end{array}$ & $\begin{array}{c}0.482 \pm \\
0.0 .39\end{array}$ & $\begin{array}{c}0.396 \pm \\
0.038^{* * *}\end{array}$ & $\begin{array}{c}0.363 \pm \\
0.038^{* * *}\end{array}$ & $\begin{array}{c}0.637 \pm \\
0.038^{* * *}\end{array}$ & 0.287 & {$[36]$} \\
\hline
\end{tabular}

Table 3. Genetic structure of cattle breeds by the $L A L B A$ gene

\begin{tabular}{|c|c|c|c|c|c|c|c|c|}
\hline \multirow{2}{*}{ Breed } & \multirow{2}{*}{$\mathrm{n}$} & \multicolumn{3}{|c|}{ Genotype frequency } & \multicolumn{2}{|c|}{ Allele frequency } & \multirow{2}{*}{$\chi^{2}$} & \multirow{2}{*}{ Source } \\
\hline & & $A / A$ & $A / B$ & $B / B$ & $A$ & $C$ & & \\
\hline $\begin{array}{c}\text { Simmental } \\
\text { (Western Siberia) }\end{array}$ & 156 & $\begin{array}{c}0.513 \pm \\
0.04\end{array}$ & $\begin{array}{c}0.429 \pm \\
0.04\end{array}$ & $\begin{array}{c}0.058 \pm \\
0.019\end{array}$ & $\begin{array}{c}0.728 \pm \\
0.025\end{array}$ & $\begin{array}{c}0.272 \pm \\
0.025\end{array}$ & 0.006 & OS \\
\hline $\begin{array}{c}\text { Russian Black Pied } \\
\text { (Belarus) }\end{array}$ & 289 & $\begin{array}{l}0.353 \pm \\
0.028^{* *}\end{array}$ & $\begin{array}{c}0.512 \pm \\
0.029\end{array}$ & $\begin{array}{l}0.135 \pm \\
0.020^{* *}\end{array}$ & $\begin{array}{l}0.609 \pm \\
0.028^{* *}\end{array}$ & $\begin{array}{l}0.391 \pm \\
0.028^{* *}\end{array}$ & 1.600 & [33] \\
\hline $\begin{array}{l}\text { Kholmogorskaya } \\
\text { (Tatarstan) }\end{array}$ & 164 & $\begin{array}{l}0.390 \pm \\
0.038^{* *}\end{array}$ & $\begin{array}{c}0.433 \pm \\
0.038\end{array}$ & $\begin{array}{c}0.177 \pm \\
0.030^{* * *}\end{array}$ & $\begin{array}{l}0.607 \pm \\
0.038^{* *}\end{array}$ & $\begin{array}{l}0.393 \pm \\
0.038^{* *}\end{array}$ & 1.414 & [36] \\
\hline
\end{tabular}

Table 4. Genetic structure of cattle breeds by the LEP gene

\begin{tabular}{|c|c|c|c|c|c|c|c|c|}
\hline \multirow{2}{*}{ Breed } & \multirow{2}{*}{$\mathrm{n}$} & \multicolumn{3}{|c|}{ Genotype frequency } & \multicolumn{2}{|c|}{ Allele frequency } & \multirow{2}{*}{$\chi^{2}$} & \multirow{2}{*}{ Source } \\
\hline & & $C / C$ & $C / T$ & $T / T$ & $C$ & $T$ & & \\
\hline $\begin{array}{c}\text { Simmental } \\
\text { (Western Siberia) }\end{array}$ & 156 & $\begin{array}{c}0.429 \pm \\
0.04\end{array}$ & $\begin{array}{c}0.481 \pm \\
0.04\end{array}$ & $\begin{array}{c}0.090 \pm \\
0.023\end{array}$ & $\begin{array}{c}0.670 \pm \\
0.027\end{array}$ & $\begin{array}{c}0.330 \pm \\
0.027\end{array}$ & 0.007 & OS \\
\hline $\begin{array}{l}\text { Holstein } \\
\text { (Tatarstan) }\end{array}$ & 228 & $\begin{array}{l}0.325 \pm \\
0.031^{*}\end{array}$ & $\begin{array}{c}0.491 \pm \\
0.033\end{array}$ & $\begin{array}{l}0.184 \pm \\
0.025^{*}\end{array}$ & $\begin{array}{l}0.570 \pm \\
0.033^{*}\end{array}$ & $\begin{array}{l}0.430 \pm \\
0.033^{*}\end{array}$ & 0.001 & [37] \\
\hline
\end{tabular}




\begin{tabular}{|c|c|c|c|c|c|c|c|c|}
\hline $\begin{array}{c}\text { Kholmogorskaya } \\
\text { (Tatarstan) }\end{array}$ & 164 & $\begin{array}{c}0.250 \pm \\
0.034^{* *}\end{array}$ & $\begin{array}{c}0.555 \pm \\
0.039\end{array}$ & $\begin{array}{c}0.195 \pm \\
0.031^{* *}\end{array}$ & $\begin{array}{l}0.570 \pm \\
0.039^{*}\end{array}$ & $\begin{array}{c}0.430 \pm \\
0.039^{*}\end{array}$ & 4.324 & {$[36]$} \\
\hline
\end{tabular}

\section{Discussion}

With the introduction of molecular genetic technologies in breeding programs for animals, it becomes possible to study the genetic structure of different breeds at the present stage of existence. Highly productive animals are a good object for studying the stability of the dynamic equilibrium of allele frequencies for genes associated with productivity traits. Long-term selection of animals only for milk productivity has already led to the transformation of the population's genetic system, as a result, life expectancy has decreased, and reproduction has decreased. The search and analysis of DNA polymorphism associated with various quantitative and qualitative characteristics of the phenotype is extremely necessary from the point of view of preserving and using the genetic resource of existing animal breeds.

Molecular genetic testing of Simmental cows bred in the Western Siberia using the studied genes showed that the population sampling is in a state of genetic equilibrium and does not experience significant influence of factors that can change its genetic structure. It is likely that the established structure for these genes was formed without the participation of selection pressure, mainly due to the use of random genotypes of breeding animals, mainly breeding bulls. However, given that bulls were not previously genotyped by these loci, and allele variants in gametes may be equally likely to be present, their contribution to the genotype distribution is stochastic. It is possible that the studied allele variants of genes are weakly affected by the pressure of natural selection and represent selectively neutral loci. The results of our own research and literature data show a low frequency of $B / B$ homozygous genotypes associated with cow protein content in the kappa-casein and betalactoglobulin genes, which is probably not due to selection against carriers of the $B$ allele, but to its later appearance as a result of the mutation process. As for the selective advantage of carriers of allele $A$, due to the prolonged selection of animals to increase milk yield, it is, in our opinion, impossible in the absence of lethality or reduced fertility of carriers of allele $B$. Given that alternative alleles of these genes are associated by some researchers with milk content and protein content in milk, which are negatively correlated with each other, it is necessary to search for complex genotypes that combine favorable combinations by different loci. Such selection will allow to identify first of all bulls-carriers of desirable alleles, and then to form the population structure and preserve genetic diversity not only in terms of general heterozygosity, but also in terms of the composition of homozygous variants of different selection-significant loci. At the same time, taking into account the complex polygenic nature of inheritance of productivity traits, it is important to maintain the quality of milk at high milk yields.

The frequency distribution of alleles in different breeds demonstrates some features of the Simmental breed's genetic structure, which are most noticeable by the $B L G$ gene. However, given that previously there was no selection in relation to the studied alleles and genotypes, the population structure of breeds was formed randomly. And when one of the alleles is rare in the population, this allele will be distributed mainly among heterozygotes, which we observe. Therefore, the presence of a sufficiently large proportion of heterozygotes for the kappa-casein $(C S N 3)$, beta-lactoglobulin $(B L G)$, alpha-lactalbumin $(L A L B A)$ and leptin $(L E P)$ genes indicates the genetic variability of the population and provides a basis for monitoring genetic diversity. 


\section{Conclusions}

1. The genetic structure of the population of the Simmental breed bred in the Western Siberia by the kappa-casein (CSN3), beta-lactoglobulin $(B L G)$, alpha-lactalbumin ( $L A L B A)$ and leptin $(L E P)$ genes is in a state of gene equilibrium and corresponds to the theoretically expected distribution of genotypic frequencies according to the Hardy-Weinberg formula. At a given point in time, allele frequencies are not subject to change as a result of selection, migration, or mutational pressure.

2. Among three genotypic classes in each locus, the lowest frequency of occurrence was found in the $B / B$ genotypes (CSN3, BLG, LALBA) and $T / T(L E P)$, the level of which did not exceed $10 \%$. Low frequency of these homozygotes and corresponding alleles is noted in other breeds of cattle.

3. The Simmental breed is dominated by $A / A$ homozygotes of $C S N 3$ gene $(58.3 \%)$, the ratio of homozygotes and heterozygotes is approximately the same for the other genes. A high level of heterozygosity $(40-50 \%)$ indicates that the genotypic structure of the population will change very little if there is no targeted selection in favor of the desired alleles.

\section{Conflict of interest}

We certify that there is no conflict of interest with any financial organization regarding the material discussed in the manuscript.

\section{Acknowledgments}

Funding was provided within the framework of the project "Research of genetic diversity in highly productive cattle herds by polymorphic variants of genes associated with economically useful traits" under the state task of the Ministry of Agriculture of Russia (No. AAA-A20-12-001-2890007-0).

\section{References}

1. L.K. Ernst, N.A. Zinov'eva. Biological problems of livestock in XXI century (Moscow, RASHN Publ., 2008) (inRussian)

2. P. David, Heredity (Edinb), 80(Pt5), 531-537 doi:10.1046/j.1365-2540.1998.00393.x

3. M. Szulkin, N. Bierne, P. David, Evolution 64(5), 1202-1217 (2010) doi:10.1111/j.1558-5646.2010.00966.x

4. S.V. Nikitin, S.P. Knyazev, T.I. Shvebel, Russian Journal of Genetics, 45(10), 14011410 (2009) (in Russian)

5. A. Da Silva, J.M. Gaillard, N.G. Yoccoz, A.J. Hewison, M. Galan, T. Coulson, D. Allainé, L. Vial , D. Delorme, G. Van Laere, F. Klein, G. Evolution; 63(2), 403- 417 (2009) doi:10.1111/j.1558-5646.2008.00542.x.

6. Yu.P. Altukhov, Genetic processes in populations, Manual (Moscow, Academk- niga Publ., 2003) (in Russian)

7. Yu.P. Altukhov, Sorosovskii Obrazovatelnyi Zhurnal=Soros Educational Journal, 1, 32-43 (1995) (in Russian)

8. M.M. Tikhomirova, Genetics analisis (Leningrad University Publ., 1990) (in Russian)

9. A.S. Durov, V.S. Deyeva, N.G. Gamarnik, Bulletin of Altai State Agricultural 
University; 8(118), 78-81 (2014) (in Russian)

10. I.I. Klimenok, S.B. Yaranceva, M.A. Shishkina, Genetic and breeding of ani- mals, 2, 314, 30-33 (2014) (inRussian)

11. A.I. Zheltikov, Russian Black Pied cattle in Siberia (Novosibirsk, Prometei Publ., 2010) (inRussian)

12. V. Litzke, M. Ottensman, J. Forcada, L. Heitzmann, J. Ivan Hoffman, Ecol Evol, 9(14): 7985-7996 (2019) doi:10.1002/ece3.5317

13. B.K. Mable, Conservation Genetics, 20, 89-100 (2019) doi: 10.1007/s10592-018-1129-9

14. E. Peripolli, D.P. Munari, M.V.G.B. Silva, A.L.F. Lima, R. Irgang, F. Baldi, Anim Genet, 48(3), 255-271 (2017) doi:10.1111/age.12526.

15. S.S. Kramarenko, S.I. Lugovoy,V.R. Kharzinova,V.Y. Lykhach, A.S. Kramarenko, A.V. Lykhach, Regulatory Mechanisms in Biosystems, 9(2), 177-182 (2018) doi:10.15421/021826

16. L. Ollivier, Proceedings of 6th International Symposium on the Mediterranean Pig, Messina - Capo d'Orlando (ME) (Italy, 2007)

17. M.A. Toro, A. Caballero, Philos Trans R Soc Lond B Biol Sci, 360(1459), 1367-1378. (2005) doi:10.1098/rstb.2005.1680

18. A.A. Vicente, M.I. Carolino, M.C. Sousa, C. Ginja, F.S. Silva, A.M. Martinez, J.L.Vega-Pla, N. Carolino, L.T. Gama, J Anim Sci, 86(10), 2496-507 (2008) doi: $10.2527 /$ jas.2007-0691

19. D.W. Coltman, J. Slate, Evolution, 57(5), 971-983 (2003) doi:10.1111/j.00143820.2003.tb00309.x

20. M. Muñoz, R. Bozzi, J. García-Casco, Y. Núñez, A. Ribani, O. Franci, F. García, M. Škrlep, G. Schiavo, S. Bovo, V.J. Utzeri, R. Charneca, J.M. Martins, R. Quintanilla, J. Tibau, V. Margeta, I. Djurkin-Kušec, M.J. Mercat, J. Riquet, J. Estellé, C. Zimmer, V. Razmaite, J.P. Araujo, C. Radović, R. Savić, D. Karolyi, M. Gallo, M. ČandekPotokar, A.I. Fernández, L. Fontanesi, C. Óvilo, Sci Rep, 9(1), 13546 (2019) doi: 10.1038/s41598-019-49830-6.

21. G. Athrey, N. Faust, A-S.C. Hieke, I.L. Brisbin, PeerJ, 6, e5803 (2018) doi: 10.7717/peerj.5803

22. S.G. Inge-Vechtomov, Genetics with the basics of breeding (Moscow, Vyschayashkola publ., 1989) (inRussian)

23. R.A. Khaertdinov, M.P. Afanas`ev, R.R. Khaertdinov. Proteins of the milk (Kazan', Idel-Press Publ., 2009, 256 pp.) (inRussian)

24. R.A. Khaertdinov, I.N. Kamaldinov, R.R. Islamov, Scientific notes of the Kazan State Academy of Veterinary Medicine, KSAVM, 219, 319-324 (2014)

25. G. Banos, J.A. Woolliams, B.W. Woodward, A.B. Forbes, M.P. Coffey, J Dairy Sci, 91(8), 3190-200 (2008) doi:10.3168/jds.2007-0930.

26. V.M. Kuznetsov, Problemy biologii produktivnykh zhivotnykh $=$ Problems of biology of productive animals, 4, 80-104 (2014) (inRussian)

27. L.A. Zhivotovskiy, Populational Biometry (Moscow, Nauka Publ., 1991) (inRussian)

28. E.K. Merkur'eva. Base of Biometry (Moscow State University Publ., 1963) (in Russian)

29. G.L. Gromyko, Theory of statistics, Under the editorship prof (Moscow, INFRA-M Publ., 2010) (inRussian) 
30. Markov, E. Naimark, Evolution, Classical Ideas in the Light of New Discoveries (Moscow, ACT: CORPUS Publ., 2015) (in Russian)

31. S.V. Nikitin, S.P. Knyazev, Selection and adaptation in domestic pigpopulations (Saarbrucken: Lambert Academy Publ., 2015.) (in Russian)

32. L.A. Kalashnikova, Ya.A. Khabibrakhmanova, I.Yu. Pavlova, T.B. Ganchenkova, I.M. Dunin, I.E. Pridanova, Recommendations for genomic assessment of cattle (Lesnye Polyany, 2015)

33. T. Lupolova, A. Ganja, Ya. Kuleshevich, Ştiinţa agricolă, 1, 160-166 (2020) doi: 10.5281/zenodo.3911645 (inRussian)

34. L.R. Zagidullin, R.R. Shaydullin, T.M. Akhmetov, S.V. Tyul'kin, Molochnokhozyaistvenny Vestnik; 37(1), 24-34 (2020) (inRussian)

35. Yu.R. Yulmeteva, N.Yu. Safina, Sh.K. Shakirov, Aktualnye voprosy veterinarnoi biologii =Current issues of veterinary biology, 38(2), 9-12 (2018) (inRussian)

36. S.V. Tyulkin. Molecular genetic testing of cattle for the genes of milk proteins, hormones, enzymes and hereditary diseases (D Thesis, federal state budgetary educational institution higher education institution kazan state academy of veterinary medicine bauman university of medicine, Kazan, Russia) (2019) (in Russian)

37. M.I. Varlamova, N.Yu. Safna, Sh.K. Shakirov, E.R. Gaynutdinova, A.M. Alimov, Aktualnye voprosy veterinarnoi biologii $=$ Current issues of veterinary biology, 47(3), 3-6 (2020) (in Russian) doi:10.24411/2074-5036-2020-10022 